\title{
Dermatological Manifestations of COVID-19: A Review Based on Existing Reports
}

\section{Tarun Kumar ${ }^{1}$, Siddhartha Dutta ${ }^{1 *}$, Rajit Sahai ${ }^{1}$, Sameer Khasbage ${ }^{2}$, Rajesh Kumar ${ }^{1}$, Sudeshna Banerjee ${ }^{3}$}

Sci. Journal Impact

Factor: 6.1 (2018)

ICV: 90.90 (2018)

Scopus'

\begin{abstract}
'Senior Resident, Department of Pharmacology, All India Institute of Medical Sciences (AllMS), Jodhpur-342005, Rajasthan, India; ']unior Resident, Department of Pharmacology, All India Institute of Medical Sciences (AllMS), Jodhpur-342005, Rajasthan, India; ${ }^{3 S e n i o r ~ L e c-~}$ turer, RSVM college of Nursing, Jodhpur.
\end{abstract}

\section{ABSTRACT}

The pandemic of severe acute respiratory syndrome Coronavirus 2(SARS-CoV-2) infections started with few unknown cases of pneumonia associated with the Wuhan district of China. This has led to a huge load of cases and deaths due globally these days. As of now, most infections are self-limiting, and approximately $15 \%$ of infected adults can turn up critical to developing severe pneumonia and requires supplemental oxygen therapy. The causative virus was isolated from lower respiratory tract samples of infected patients, found to be a novel Coronavirus (nCoV). The clinical signs and symptoms of COVID-19 are highly variable and include the most common symptoms as fever, dry cough, and fatigue. This highly infectious virus usually affects the respiratory tract; hence the cutaneous manifestations are often ignored and not reported. Cutaneous manifestations are quite common in various viral infections, and the scenario can be similar in COVID-19. The asymptomatic period of about 14 days, even after infection leads to a delay in the diagnosis of this condition. In view of such conditions, cutaneous manifestations if present can serve as a signal for the incubating infection. High levels of clinical suspicion and judgment can diagnose the condition early hence help in early intervention. This article reviews all the possible dermatological manifestations reported in the patients of COVID-19 in the online scientific platforms.

Key Words: COVID-19, Coronavirus, Dermatological manifestation, Skin, SARS-CoV-2

\section{INTRODUCTION}

Presently, the whole world is in distress due to the novel Coronavirus, which has put it on a standstill. It started with few unknown cases of pneumonia associated with unusual etiology were initially reported in Wuhan district of China in December 2019. ${ }^{1}$ Later, the pathogen was isolated from lower respiratory tract samples of infected patients, found to be a novel Coronavirus (nCoV), and was named severe acute respiratory syndrome Coronavirus 2 (SARS-CoV-2). ${ }^{2}$ Earlier, the nCoVwas found to be quickly spreading inside Hubei Province, and later it got spread to other countries of the world. ${ }^{3}$ It was declared as an emergency by the World Health Organization(WHO), and later by the midst of February 2020, the SARS-CoV-2 had already spread across the world. ${ }^{2,3}$ WHO named it Coronavirus Disease 2019 (COVID-19), and further, on March 11, 2020, it was declared as a pandemic. ${ }^{2,3,4}$ As of May 10, 2020, a total of 3,862,676 cases and 265,961 deaths have been confirmed by the WHO. ${ }^{5}$ Europe, USA, Eastern Mediterranean are worst hit apart from the reach in Western Pacific, South-East Asia, and the African region. ${ }^{5}$ The clinical signs and symptoms of COVID-19 are highly variable and include common symptoms like fever, dry cough, and fatigue. ${ }^{6}$ The less common symptoms are myalgia, rhinorrhea, headache, conjunctivitis, sore throat, diarrhea, anosmia or ageusia, skin rash or discoloration of fingers or toes. ${ }^{6}$ There is also instability in the vital parameters like temperature, pulse oximetry saturation, and changes in chest radiological findings in X-ray and Chest CT scan. ${ }^{7}$ In COVID-19, the patients most report with respiratory symptoms, which can range from mild flu to severe respiratory distress. ${ }^{7}$ The SARS-CoV-2 virus enters the cells through the angiotensin-converting enzyme 2 (ACE2) receptor, found on the surface of cells, and lungs are the primary site of infection. ${ }^{8,9}$ Of the above varied symptoms mentioned, all symptoms are not essentially present in every successive patient, and besides, as this infective disease is primarily respiratory in nature, for this reason, the cutaneous manifestations have not been widely reported. ${ }^{7}$ This article is a review of all the possible dermatological manifestations reported by various

\section{Corresponding Author:}

Dr. Siddhartha Dutta, Senior Resident, Department of Pharmacology, All India Institute of Medical Sciences (AlIMS), Jodhpur-342005, Rajasthan, India; Contact: +919958462048; Email: siddhartha.dutta87@gmail.com; ORCHID ID: 0000-0001-6525-5950

ISSN: 2231-2196 (Print)

Received: 12.05 .2020
ISSN: $0975-5241$ (Online)

Revised: 08.06.2020
Accepted: 20.06 .2020 
researchers as reported by them in the online scientific platforms and indexed journals.

\section{Dermatological manifestation of COVID-19}

An early report by Recalcati S et al.. stated that dermatologists working with COVID-19 patients in Italy analyzed a group of 88 confirmed positive patients, among which 18 developed skin symptoms. ${ }^{10}$ Eight patients got the skin symptoms at the onset, and 10 of them developed it after hospitalization. Amongst the COVID-19 patients, the most familiar expression of all was the presence of an erythematous rash or a patchy red rash. A few developed widespread urticaria or hives, and one developed chickenpox-like blisters. ${ }^{10}$ The trunk was the most familiar site to be affected, and the pruritis was associated with the lesions being low or even absent. The lesions were seen to heal within a few days, and they could not find any correlation with the severity of the disease. ${ }^{10}$

A report from Thailand, Joob B et al. 2020, described a COVID-19 patient who was initially misdiagnosed with dengue fever. He presented with petechiae and rash common as seen in dengue. Later on, the patient developed respiratory distress and was found to be $2019-\mathrm{CoV}$ positive. ${ }^{11}$ Y. Zhang et al. from Wuhan(China), reported cases of Acro-ischemia with finger/toe cyanosis, skin bulla and dry gangrene in 7 patients. ${ }^{12} \mathrm{~J}$. Jimenez-Cauhe et al. reported a case from Spain stating Erythemato-purpuric, coalescing macules in Flexural and peri-axillary regions within 3 days of hospitalization. ${ }^{13}$ Henry et al. from France reported a case with disseminated erythematous plaques eruption on face, hand and feet within 48 hours before the onset of respiratory symptoms and associated with pruritis.$^{14}$ Estébanez et al. from Spain reported a case with pruritic lesions/ confluent, erythematous-yellowish papules on the heel, 13 days after being positive of SARS$\mathrm{CoV}-2$. The lesions persisted and got hardened and pruritic. ${ }^{15}$ Similar reports from Tehran, Iran by Kamali Aghdam stated Cutaneous mottling in a 15-day-old neonate who was admitted with fever, lethargy and respiratory distress without cough. ${ }^{16}$ Mazzotta et al. reported a case from Italy stating a 13-year-old male with erythematous-violet, rounded lesions with blurred limits on the plantar surface of 1 st right toe and dorsal surface of the 2nd toe on both feet associated with intense itching andburning on the foot lesions. ${ }^{17}$ Alramthan et al. from Qatar reported acral ischemic lesions presenting as red-purple papules on the dorsal aspect of fingers. ${ }^{18}$ Athanassios Kolivras et al. from Brussels, Belgium stated a case report with acute-onset, violaceous, infiltrated, and painful plaques on the toes and lateral aspect of the feet which began 3 days after onset of respiratory symptoms and a dry cough. ${ }^{19}$ Sachdeva et al. from Milan, Italy reported 3 cases of dermatological manifestation associated with COVID-19.
The dermatological manifestation varied presentation like a maculopapular itchy rash resembling Grover disease, diffuse maculopapular exanthema(morbilliform), macular hemorrhagic rash, Papular-vesicular, and pruritic eruption. ${ }^{20}$ In their review of 1099 cases of COVID-19 infection from mainland China, Guan et al. reported 2 patients $(0.2 \%)$ had a rash. ${ }^{21}$

C. Galván Casas et al. did a nationwide survey of 375 cases in Spain and classified the dermatological manifestation into five types of clinical patterns. The authors stated that the vesicular eruptions were seen to appear early in the course of the disease whereas, the pseudo-chilblain pattern seems to have a delayed appearance in the course of the COVID-19 disease. $^{22}$

The skin lesions of COVID-19 patients were classified as given in table I.

Table I: Summary of classification of the dermatological manifestation done by C. Galván Casas et al. in Spain. ${ }^{22}$

\begin{tabular}{|c|c|c|c|}
\hline $\begin{array}{l}\text { Serial } \\
\text { number }\end{array}$ & $\begin{array}{l}\text { Dermatological } \\
\text { manifestation }\end{array}$ & $\begin{array}{l}\text { Additional char- } \\
\text { acteristics }\end{array}$ & Percentage \\
\hline 1 & $\begin{array}{l}\text { Erythema with } \\
\text { vesicles or pustules } \\
\text { in the acral area } \\
\text { (Pseudo-chilblain) }\end{array}$ & $\begin{array}{l}\text { Asymmetrical } \\
\text { lesions that re- } \\
\text { sembled chilblains } \\
\text { and also had pur- } \\
\text { puric areas mostly } \\
\text { affecting hands } \\
\text { and feet. }\end{array}$ & $19 \%$ \\
\hline 2 & $\begin{array}{l}\text { Other vesicular } \\
\text { eruptions }\end{array}$ & $\begin{array}{l}\text { Small monomor- } \\
\text { phic vesicles seen } \\
\text { on the trunk and } \\
\text { also seen on the } \\
\text { limbs with haem- } \\
\text { orrhagic content. }\end{array}$ & $9 \%$ \\
\hline 3 & Urticarial lesions & $\begin{array}{l}\text { The trunk was } \\
\text { most common site } \\
\text { apart from the pal- } \\
\text { mar region }\end{array}$ & $19 \%$ \\
\hline 4 & $\begin{array}{l}\text { Maculopapular } \\
\text { eruptions }\end{array}$ & $\begin{array}{l}\text { Few had perifol- } \\
\text { licular distribu- } \\
\text { tion with varying } \\
\text { degrees of scaling. } \\
\text { Purpura was also } \\
\text { seen. Infiltrated } \\
\text { papules in the ex- } \\
\text { tremities, mostly } \\
\text { dorsum of the } \\
\text { hands were seen in } \\
\text { few cases }\end{array}$ & $47 \%$ \\
\hline 5 & Livedo or necrosis & $\begin{array}{l}\text { Presented as } \\
\text { varying degrees of } \\
\text { lesions resembling } \\
\text { vaso-occlusive } \\
\text { disorder which } \\
\text { involved the trunk } \\
\text { or acral areas }\end{array}$ & $6 \%$ \\
\hline
\end{tabular}




\section{COVID toes}

Sarah Young, in an article, mentions "COVID toes is a nonspecific term that describes a purple or pink discoloration often with papules involving the tips of the toes. There can be varied causes, among which impaired blood flow to the toes or chilblain-like toes can be one of them." ${ }^{23}$ In view of the fact that COVID-19 is creating a pro-inflammatory state, therefore the patients have a higher risk of developing clots. Though, they could not conclude because of the lack of robust evidence and early findings but stated that systemic inflammation and clotting can be an apparent cause of COVID toes. ${ }^{23,24}$

\section{CONCLUSION}

The presentation of rash or cutaneous manifestation associated with has been found to have a varied or diverse manifestation. It can confuse the medical practitioner between rashes like hives, a drug reaction, or chilblains. The preexisting rash in cases of COVID-19 before showing the respiratory symptoms makes it hard to pick up and easy to miss the cases from early diagnosis of COVID-19. Due to the lack of enough data and evidence, the typical or diagnostic presentation of the rash in COVID-19 has been a grey area till now. Until more is known, clinicians must have a high intent of suspicion regarding any cases of rash that comes to them. The rash should drive the physician to enquire regarding other symptoms of COVID-19 with a proper history, and other clinical clues, to decide whether the patient should be tested for the disease. This will ascertain an early diagnosis and treatment of the patient suffering from COVID-19.

\section{ACKNOWLEDGMENT}

Authors acknowledge the immense help received from the scholars whose articles are cited and included in references of this manuscript. The authors are also grateful to authors / editors / publishers of all those articles, journals and books from where the literature for this article has been reviewed and discussed.

Conflict of Interest: None declared

Source of funding: No source of funding

\section{REFERENCES}

1. Jin YH, Cai L, Cheng ZS, Cheng H, Deng T, Fan YP et al., for the Zhongnan Hospital of Wuhan University Novel Coronavirus Management and Research Team, Evidence-Based Medicine Chapter of China International Exchange and Promotive Association for Medical and Health Care (CPAM). A rapid advice guideline for the diagnosis and treatment of 2019 novel Coronavirus (2019-nCoV) infected pneumonia (standard version). Mil
Med Res. 2020 February 6;7(1):4. doi: 10.1186/s40779-0200233-6.

2. Rolling updates on Coronavirus disease (COVID-19). Summary: World Health Organization (WHO).Cited from URL: https:// www.who.int/emergencies/diseases/novel-Coronavirus-2019/ events-as-they-happen[Accessed on May 5, 2020]

3. WHO Timeline - COVID-19: World Health Organization (WHO). Cited from URL: https://www.who.int/news-room/ detail/27-04-2020-who-timeline---covid-19 [Accessed on May 8 2020]

4. Ng OT, Marimuthu K, Chia PY, et al.. SARS-CoV-2 infection among travelers returning from Wuhan, China. N Engl J Med. 2020 March 12. doi: 10.1056/NEJMc2003100. [Epub ahead of print].

5. WHO Coronavirus Disease (COVID-19) Dashboard. World Health Organization (WHO). Cited from URL: https://covid19. who.int/ [Accessed on May 10, 2020]

6. What are the symptoms of COVID-19? Q\&A on Coronaviruses (COVID-19): WHO TEAM Health Emergencies Preparedness and Response. Cited from URL: https:/www.who.int/emergencies/diseases/novel-Coronavirus-2019/question-and-answershub/q-a-detail/q-a-Coronaviruses [Accessed on May 10, 2020]

7. Wang $\mathrm{D}, \mathrm{Hu} \mathrm{B}, \mathrm{Hu} \mathrm{C}$ et al. Clinical Characteristics of 138 Hospitalized Patients With 2019 Novel Coronavirus-Infected Pneumonia in Wuhan, China. JAMA. 2020 Feb 7. doi: 10.1001/ jama.2020.1585. [Epub ahead of print].

8. Guo YR, Cao QD, Hong ZS, Tan YY, Chen SD, Jin HJ, et al. The origin, transmission and clinical therapies on Coronavirus disease 2019(COVID-19) outbreak - an update on the status. Mil Med Res. 2020 March 13;7(1):11. doi: 10.1186/s40779020-00240-0

9. Zhai P, Ding Y, Wu X, Long J, Zhong Y, Li Y. The epidemiology, diagnosis and treatment of COVID-19. Int J Antimicrob Agents. 2020 Mar 28:105955. doi: 10.1016/j.ijantimicag.2020.105955. [Epub ahead of print]

10. Recalcati S. Cutaneous manifestations in COVID-19: a first perspective. J Eur Acad Dermatol Venereol. 2020 March 26. doi: 10.1111/jdv.16387. [Epub ahead of print] PubMed PMID: 32215952.

11. Joob B, Wiwanitkitet V. COVID-19, can present with a rash and be mistaken for dengue. J Am. Acad. Dermatol. 82 May (2020) e177.DOI: https://doi.org/10.1016/j.jaad.2020.03.036

12. Zhang Y, Cao W, Xiao M, Li YJ, Yang Y, Zhao J, Zhou X, Jiang W, Zhao YQ, Zhang SY, Li TS. [Clinical and coagulation characteristics of 7 patients with critical COVID-2019 pneumonia and acro-ischemia]. Zhonghua Xue Ye Xue Za Zhi. 2020 Mar 28;41(0):E006. Chinese. doi: 10.3760/ cma.j.issn.0253-2727.2020.0006. Epub ahead of print. PMID: 32220276.

13. J. Jimenez-Cauhe, D. Ortega-Quijano, M. Prieto-Barrios, Om Moreno-Arrones, D. Fernandez-Nieto, Reply to "COVID-19 can present with a rash and bemistaken for Dengue": petechial rash in a patient with COVID-19 infection. J. Am. Acad. Dermatol. April 10, 2020; pii: S0190-9622(20)30556-9.doi:http:// dx.doi.org/10.1016/j.jaad.2020.04.016 [Epub ahead of print].

14. D. Fernandez-Nieto, D. Ortega-Quijano, G. Segurado-Miravalles, C. Pindado Ortega, M. Prieto-Barrios, J. Jimenez-Cauhe, Comment on: cutaneous manifestations in COVID-19: a first perspective. Safety concerns of clinical images and skin biopsies, J. Eur. Acad. Dermatol. Venereol. (April 15) (2020), doi: http://dx.doi.org/10.1111/jdv.16470 [Epub ahead of print]

15. A. Estébanez, L. Pérez-Santiago, E. Silva, S. Guillen-Climent, A García-Vázquez,M. Ramón. Cutaneous manifestations in COVID-19: a new contribution, J. Eur. Acad. Dermatol. Venereol. (April 
15) (2020), doi:http://dx.doi.org/10.1111/jdv.16474 [Epub ahead of print].

16. M. KamaliAghdam, N. Jafari, K. Eftekhari. Novel Coronavirus in a 15-day-old neonate with clinical signs of sepsis, a case report, Infect. Dis. (Lond). 52 (June6) (2020) 427-429, doi:http:// dx.doi.org/10.1080/23744235.2020.1747634Epub 2020 Apr 1

17. F. Mazzotta, T. Troccoli, Acute Acro-Ischemia in the Child at the time of COVID-19. DermatologiaPediatrica, Bari, (2020) In press. Cited from URL:https://www.fip-ifp.org/wp-content/ uploads/2020/04/acroischemia-ENG.pdf [Accessed on May 10, 2020]

18. A. Alramthan, W. Aldaraji, A case of COVID-19 presenting in clinical picture resembling chilblains disease. First report from the Middle East. Clin Exp Dermatol. (2020) April 17. doi: https://doi.org/10.1111/ced.14243. [Epubahead of print]

19. Kolivras A, Dehavay F, Delplace D, Feoli F, Meiers I, Milone L. Coronavirus (COVID-19) infection-induced chilblains: A case report with histopathologic findings. JAAD Case Rep. 2020 Apr 18. doi: 10.1016/j.jdcr.2020.04.011. [Epub ahead of print]

20. Sachdeva M, Gianotti R, Shah M, Lucia B, Tosi D, Veraldi S et al. Cutaneous manifestations of COVID-19: Report of three cases and a review of literature. J Dermatol Sci. 2020 Apr 29:S0923-
1811(20)30149-3. doi: 10.1016/j.jdermsci.2020.04.011. Epub ahead of print. PMID: 32381430; PMCID: PMC7189855.

21. Guan WJ, Ni ZY, Hu Y, Liang WH, et al. Clinical characteristics of Coronavirus disease 2019 in China. New Engl J Med 2020 Feb 28.doi: 10.1056/NEJMoa2002032 [Epub ahead of print].

22. C. GalvánCasas A.Català G. Carretero Hernández P. Rodríguez-Jiménez D. Fernández Nieto A. Rodríguez-Villa Lario et al. Classification of the cutaneous manifestations of COVID-19: a rapid prospective nationwide consensus study in Spain with 375 cases. Br. J. Dermatol 2020 April 29. doi: https://doi. org/10.1111/bjd.19163 [Epub ahead of print]

23. COVID Toes and Other Rashes Associated with COVID-19. Consult QD: Dermatology\& Plastic Surgery / News \& Insights, Cleveland Clinic. Cited from URL: https://consultqd.clevelandclinic.org/covid-toes-and-other-rashes-associated-with-covid-19/ [Accessed on May 10, 2020]

24. Skin Rashes: An Emerging Symptom of COVID-19. Consult QD: Dermatology \& Plastic Surgery / News \& Insights, Cleveland Clinic. Cited from URL:https://consultqd.clevelandclinic. org/skin-rashes-an-emerging-symptom-of-COVID-19/[Accessed on May 10, 2020] 